Turkish Online Journal of Qualitative Inquiry (TOJQI)

Volume 9, Issue 3, July 2018: 262-287 / Cilt 9, Sayı 3, Temmuz 2018: 262-287

DOI: $10.17569 /$ tojqi.426308

Research Article / Araştırma Makalesi

\title{
The Digital Storytelling Adventures of the Teacher Candidates 1
}

\author{
Burcu Anılan², Asiye Berber ${ }^{3}$, Hüseyin Anılan ${ }^{4}$
}

\begin{abstract}
The digital stories enable the students to understand the nature of science easier by means of technology. In this context, it is essential that there are the teachers, who are able to educate the creative thinking individuals that are dominant to the scientific processes and to offer any learning environments in which qualified education can be provided to their students. For this purpose, the science teacher candidates are required to create digital stories on the science subjects and achievements of $3^{\text {rd }}$ and $4^{\text {th }}$ grades by using the technology. An interview form designed by the researchers was prepared to determine the opinions of the teacher candidates about their experience in digital story preparation and the use of digital story in science teaching. With this interview form, the data of the researchers was collected by taking the voice record of the teacher candidates. The interviews were solved by descriptive analysis technique. As a result, the teacher candidates stated that the digital stories should be included in the science lessons, that the digital stories paid attention to the subject, and were fun and avocatory, and that permanent learning was provided. The teacher candidates stated that they would benefit from the digital stories in their professional lives, that the digital stories would be effective in science teaching, and that the teacher candidates notices the importance of using the technology in the science courses in these applications.
\end{abstract}

Keywords: Science, digital storytelling, teacher candidate.

\footnotetext{
${ }^{1}$ The initial findings of the study were presented at the "Vth International Eurasian Educational Research Congress" held in Antalya (Turkey) on 5th May 2018.

${ }^{2}$ Asst.Prof.Dr., Eskişehir Osmangazi University, Faculty of Education, Department of Mathematics and Science Education, anilan.burcu@gmail.com, https://orcid.org/0000-0002-4153-1866.

${ }^{3}$ Asst.Prof.Dr., Eskişehir Osmangazi University, Faculty of Education, Department of Mathematics and Science Education, asiyeberber34@gmail.com, https://orcid.org/0000-0002-8340-4793

${ }^{4}$ Assoc.Prof.Dr., Eskişehir Osmangazi University, Faculty of Education, Department of Primary Education, anilan.huseyin@gmail.com, https://orcid.org/0000-0001-7201-7467.
}

Geliş tarihi: 23.05.2018, Kabul tarihi: 30.07.2018 


\title{
Öğretmen Adaylarının Dijital Öykü Serüvenleri
}

\begin{abstract}
$\ddot{O} z$
Öğretim sürecinde teknoloji kullanımı etkili öğrenme ortamları sağlamakta, anlamayı kolaylaştırmaktadır. Eğitimde yeni yaklaşımlara ihtiyaç duyulması ve yeni yaklaşımlardan olan dijital öykülemenin ihtiyaçlara cevap verebilecek nitelikte olması, dijital öyküleme yönteminin önemini artırmıştır. Dijital öyküler öğrencilerin teknoloji yardımıyla fen bilimlerinin doğasını daha kolay anlamalarını sağlar. Bu bağlamda, bilimsel süreçlere hâkim, yaratıcı düşünen bireyleri yetiştirecek ve bu alanlarda öğrencilerine nitelikli eğitim verilebilecek öğrenme ortamları sunabilecek öğretmenlerin olması önem kazanmaktadır. Bu amaç doğrultusunda Fen Bilimleri öğretmen adaylarının teknolojiyi kullanarak 3 ve 4 .sınıf fen bilimleri konu ve kazanımlarına yönelik dijital öyküler oluşturmaları istenmiştir. Öğretmen adaylarının dijital öykü hazırlama sürecinde yaşadıkları deneyimlerinin ve dijital öykülerin fen öğretiminde kullanılmasına ilişkin görüşlerinin belirlenmesi için araştırmacılar tarafından yapılandırılmış görüşme formu hazırlanmıştır. Bu görüşme formu ile öğretmen adaylarının ses kaydı alınarak araştırmanın verileri toplanmıştır. Görüşmeler betimsel analiz tekniği ile çözümlenmiştir. Sonuç olarak, öğretmen adayları fen bilimleri derslerinde dijital öykülere yer verilmesi gerektiğini, dijital öykülerin konuya dikkat çektiğini, eğlenceli ve merak uyandırıcı olduğunu ve bu sayede kalıcı öğrenmenin sağlanacağını ifade etmişlerdir. Öğretmen adayları mesleki yaşantılarında dijital öykülerden faydalanacaklarını, fen bilimleri öğretiminde dijital öykülerin etkili olacağını ve bu uygulamalarla fen bilimleri derslerinde teknoloji kullanımının öneminin farkına vardıklarını belirtmişlerdir.
\end{abstract}

Anahtar Sözcükler: Fen bilimleri, dijital öyküleme, öğretmen adayl. 


\section{Introduction}

Today, the rapid development of the information and communication technologies has accompanied the effective use of technology in the teaching process. Increasing use of technology in in-class activities, the subjects such as increase of technology use and teaching integration of technology has become more important day by day. As a result of the developments in the information technologies, and visual and audio material computer animation, simulation, etc. have been developed and used in education (Schnotz, 2001). Development of educational programs and the provision of internet connection in the schools support the use of technology in education. The use of technology facilitates the learning, providing effective learning environments in the teaching process (Gömleksiz, 2004).

The use of technology in education has increased more day by day since the courses begin to be taught by using tablet PCs or computers in the schools. Nowadays, the individuals are expected to have an effective communication, to work flexibly and harmoniously in team spirit and in cooperation, to become information-media and technology literate, to think creatively and critically, to solve any problems, to produce anything, to develop their social and cultural skills, know how learn, and to have any skills of $21^{\text {st }}$ century such as self-arrangement capability. The education systems should also be organized so that training programs can gain these skills to train individuals with these skills. The education and training activities should be organized in this way, and the methods and techniques to be used should serve this purpose, and new approaches should be adopted to ensure that the learning environments that support interaction and cooperation and are rich with the technological tools and software are developed (Kotluk \& Kocakaya, 2015).

One of these approaches can be the digital storytelling method. The use of technology in the teaching process provides effective learning environments, making it easier to understand. The fact that the new approaches are required in education and the fact that the digital storytelling among the new approaches has a nature to capable of responding to needs has increased the importance of digital storytelling method. It may also be preferred as a learning tool because digital story may be used in the schools (Balaman, 2016). Digital storytelling is an education 
technology having almost all skills in gaining the skills of $21^{\text {st }}$ century (Jakes, 2006). Digital storytelling is a version of the traditional story modernized by technology.

Digital storytelling includes the steps of writing the stories related to the selected topic, recording the written story through the microphone, creating the images, adding the sound and images to the software, combining the added images to sound, giving the movie any effects if the software is appropriate and converting the work into video format (Balaman, 2016).

The stories can be used as effective tools for learning, because they may be remembered easily. Through digital storytelling, the children not only make the learning fun, attractive and creative, but also contribute to development of their reading, listening, writing and speaking skills. Since the digital stories are story-based, they address to most senses. Therefore, the digital stories have a potential to focus the student on the course among several different learning styles by implementing both individual and team works. Any persons, who create or apply the digital stories, have a strong learning, reflection, self-discovery, liberation, empathy and discovery potential (Boase, 2008; Cole, Street \& Felt, 2013; Raven \& O'Donnell, 2010). However, in the story efficiencies, the children find an opportunity to solve any problems, to reveal their imagination, to develop their creativeness and to reflect their experiences in their inner world. It prevents the students from being bored by helping them to focus their interest on the subject With the digital storytelling, the scientific words, definitions, terms and theories, which constitute the basis of science and which are difficult to understand frequently used contents, are presented to students in a more comprehensible, pleasurable and interesting way (Tsou, Wang \& Tzeng, cited by Suwardy, Pan \& Seow, 2013)

The digital stories help students to understand the nature of science easier by means of technology. In this context, it is important that teachers are able to educate creative thinking individuals in scientific processes and to offer learning environments in which qualified education can be provided to their students. By preparing a digital story, a teacher candidate, who writes her own story about any subject, may implement a more permanent learning by taking part in high level cognitive activities such as synthesis and evaluation (Turgut \& Kışla, 2015). For this purpose, the science teacher candidates are required to create digital stories on the science subjects and achievements of $3^{\text {rd }}$ and $4^{\text {th }}$ grades by using the technology. Thus, any answers to the following questions are required in our study: 
- What are the experiences of the science candidates on the science subjects and achievements of $3^{\text {rd }}$ and $4^{\text {th }}$ grades?

- What are the opinions of the science teacher candidates about use of the digital story in science teaching?

\section{Methodology}

This study, which aims at determining the opinions of the teacher candidates about their digital story creation experiences and the use of the digital stories in science teaching is based on the basic qualitative research design, because the main purpose of the qualitative research is to understand the complex world of human experiences and human behaviors from the point of view of the participants. In this research, basic qualitative research design is adopted because it aims to determine what experiences of science teacher candidates to create a digital story are and how opinions of the teacher candidates about use of the digital stories in teaching science.

\section{Participants}

The participants of the study were students, who study in the second grade of science education in the department of mathematics and science education in the spring semester of 2016-2017 academic year and receive the course "life language chemistry" as an elective course. The students, who were included in the study, were determined according to the criterion sampling. In this context, the fact that the teacher candidates were willing and volunteer to participate in the research, received the compulsory computer courses and were successful was determined as a criterion. The study was conducted with 7 students who met both of such criteria.

\section{Data Collection}

The research data was obtained in 20 lessons totally within the scope of the course "life science chemistry," which is opened in $2^{\text {nd }}$ grade of science education and an elective course. Because the students, who participated in the research, were expected to create a digital story by using the GoAnimate software, firstly the participants were provided with a training by a field 
specialist on use and application of the GoAnimate software program and then on the scope and characteristics of the digital stories to be created by the researchers. Then, the teacher candidates selected the subject on the science teaching program and achievements of $3^{\text {rd }}$ and $4^{\text {th }}$ grades, and conducted any researches and preparations on the contents of the stories to be created in accordance with such subject and achievements selected by them. They prepared the scenarios and each of them wrote according to these scenarios. Finally, they transformed these scenarios to a digital story by using the GoAnimate software (Figure 1).

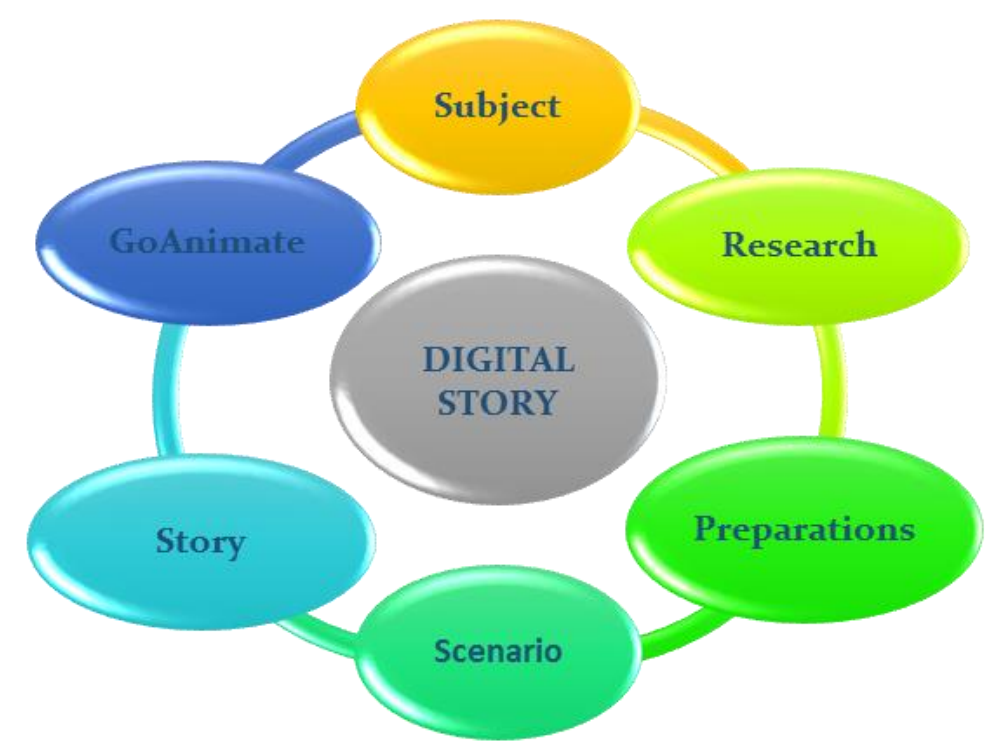

Figure 1. Digital story creation stages

After this stage of the research, the opinions were gathered by the researchers in the structured interview form prepared to determine the opinions of the prospective teachers about their experience during the digital story preparation process and the use of the digital stories in science teaching. The first part of the structured interview form consists of questions about to determine the opinions of the prospective teachers about their experience during the digital story preparation process. The questions including the opinions of the teacher candidates on use of the stories and digital studies in science teaching is related to use of the stories in science, advantages and disadvantages of the stories in science teaching, use of the technology in the story applications in the science teaching, digital stories, use of the digital stories in professional life 


\section{Data Analysis}

The collected data was analyzed using the descriptive analysis technique. The descriptive analysis is a type of qualitative data analysis that summarizes and interprets the data obtained by various data collection techniques according to pre-determined themes. In this type of analysis, the researcher can often give a place to the direct references to reflect the opinions of the individuals interviewed or observed by the researcher dramatically. The main purpose of this type of analysis is to present the obtained findings in a summarized and interpreted way to the reader (Yıldırım \& Şimşek, 2003). In this context, the interview questions asked in the study were determined as the main themes. In the study, a code was assigned to each teacher candidate. In the study, the participants' responses to the interview questions were addressed in a clear and simple way, and furthermore, any direct quotations were drawn from the opinions of the participants.

\section{Table 1}

The Unit, Subject and Achievement Correlations of the Digital Stories.

\begin{tabular}{|c|c|c|c|c|}
\hline $\begin{array}{l}\text { Teacher } \\
\text { Candidate }\end{array}$ & $\begin{array}{l}\text { Story } \\
\text { Name }\end{array}$ & Unit & Subject & Achievement \\
\hline $\mathbf{T}_{1}$ & $\begin{array}{l}\text { Ali and } \\
\text { his Plant }\end{array}$ & $\begin{array}{l}\text { F.3.6. Journey to the World of } \\
\text { Creatures / Creatures and Life }\end{array}$ & $\begin{array}{l}\text { F.3.6.1 } \\
\text { We Know the Creatures Around } \\
\text { Us. }\end{array}$ & $\begin{array}{l}\text { F.3.6.1. } 2 \\
\text { He/She observes the life cycle of a plant. }\end{array}$ \\
\hline $\mathbf{T}_{2}$ & $\begin{array}{l}\text { Little } \\
\text { Dreams }\end{array}$ & $\begin{array}{l}\text { F.3.6. Journey to the World of } \\
\text { Creatures / Creatures and Life }\end{array}$ & $\begin{array}{l}\text { F.3.6.2. } \\
\text { Me and My Environment }\end{array}$ & $\begin{array}{l}\text { F.3.6.2. } 6 \\
\text { He/She makes a research and offers any } \\
\text { solutions to protect the environment. }\end{array}$ \\
\hline $\mathbf{T}_{\mathbf{3}}$ & $\begin{array}{l}\text { I'm Wet } \\
\text { and } \\
\text { Sank. }\end{array}$ & $\begin{array}{l}\text { F.4.4. Characteristics of the } \\
\text { Substance/Substance and Its } \\
\text { Nature }\end{array}$ & $\begin{array}{l}\text { F.4.4.1. Characteristics of the } \\
\text { Substance }\end{array}$ & $\begin{array}{l}\text { F.4.4.1.1. He/She describes the basic } \\
\text { characteristics that characterize the } \\
\text { substance by using five sense organs. }\end{array}$ \\
\hline $\mathbf{T}_{4}$ & $\begin{array}{l}\text { Ali Is In } \\
\text { the } \\
\text { Kitchen. }\end{array}$ & $\begin{array}{l}\text { F.3.4. We Know the Substance } \\
\text { / Substance and Its Nature } \\
\text { F.4.4. Characteristics of the } \\
\text { Substance/Substance and Its } \\
\text { Nature }\end{array}$ & $\begin{array}{l}\text { F.4.4.1. Characteristics of the } \\
\text { Substance } \\
\text { F.4.4.2. Measurable Properties } \\
\text { of the Substance }\end{array}$ & $\begin{array}{l}\text { F.4.4.1.1. He/She describes the basic } \\
\text { characteristics that characterize the } \\
\text { substance by using five sense organs. } \\
\text { F.4.4.2.1. He/She measures masses and } \\
\text { volumes of different substances. } \\
\text { F.4.4.2.2. He/She defines the substance } \\
\text { by using its measurable properties. }\end{array}$ \\
\hline
\end{tabular}




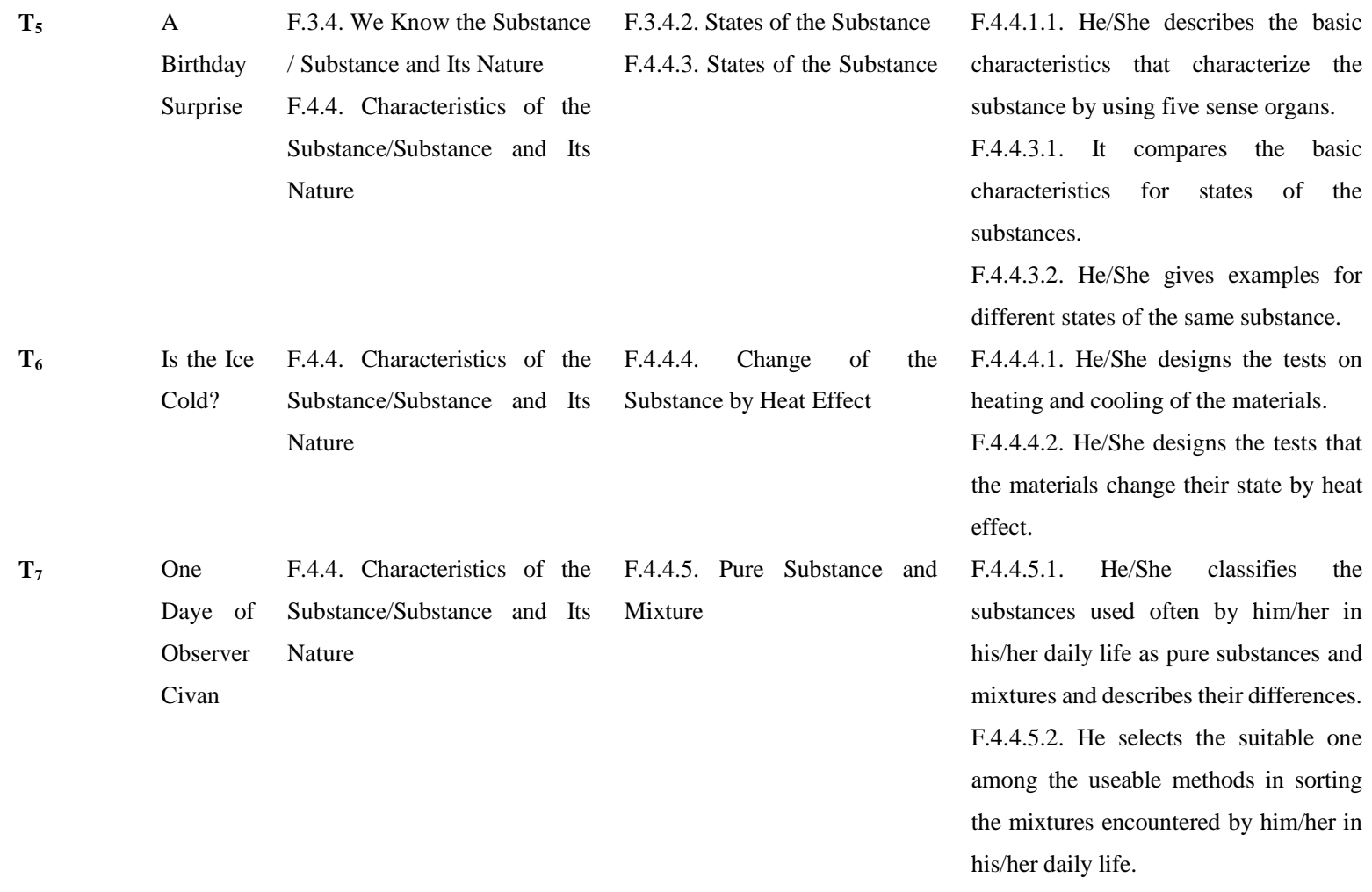

\section{Findings}

The findings obtained the data collected in this study, which aimed to determine the opinions of the Science Teacher candidates about their experiences on creation of the digital stories and the use of the digital stories in the science teaching, were found out by addressing directly the digital story images and the statements of the teacher candidates. Firstly, the names and related units, subjects and achievements of the digital stories prepared by the teacher candidates are given in Table 1.

As the examples of the digital stories created by the teacher candidates, the display images for the digital story "Birthday Surprise" prepared by T5 on the subject and achievements of the science course of $3^{\text {rd }}$ and $4^{\text {th }}$ grades are shown in Figure 2. 

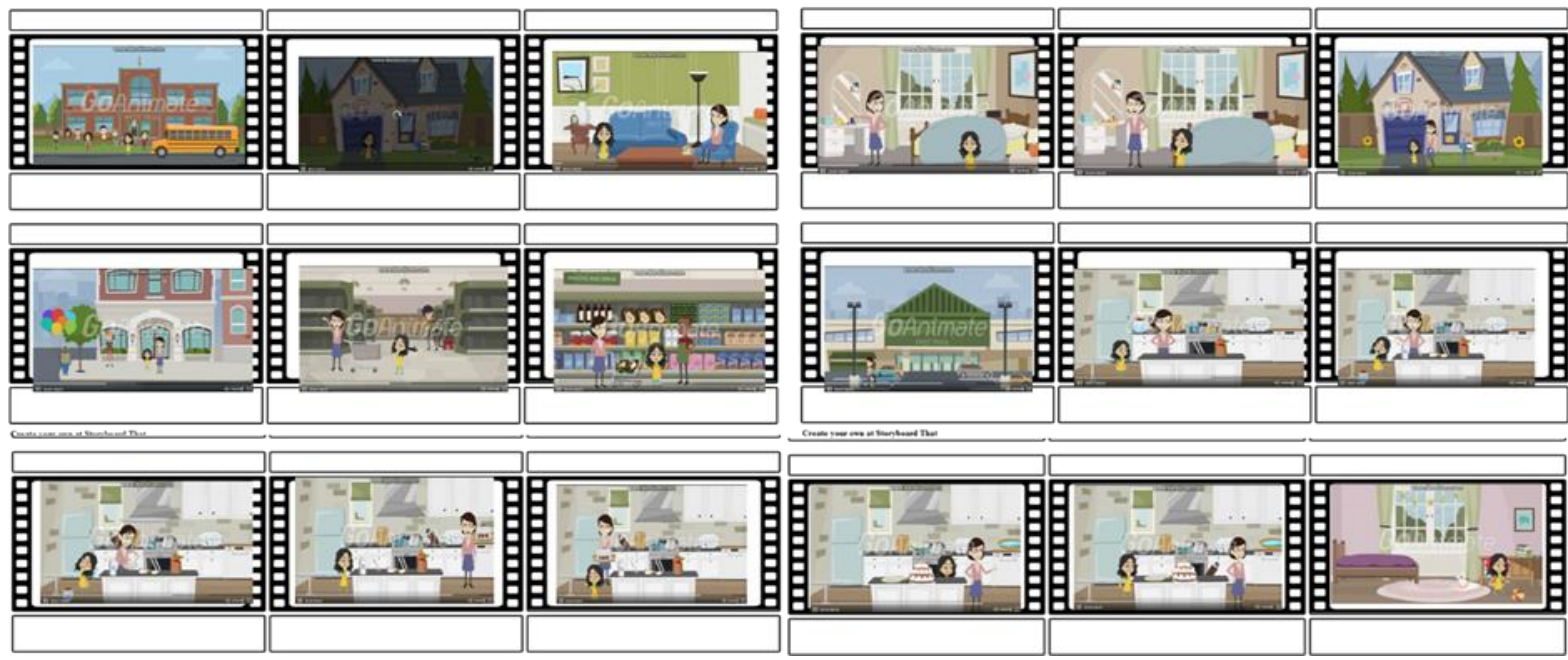

Figure 2. Images of the digital story "Birthday Surprise."

The findings are evaluated under two main themes as the experiences of the teacher candidates on digital story creation and their opinions on the use of digital stories in science teaching.

\section{The Experiences of the Teacher Candidates on Digital Story Creation}

By considering the expressions of the students on the experiences of the teacher candidates on 'digital story creation,' the experiences of the teacher candidates on writing and transferring their stories to the digital media were evaluated under two sub-themes

\section{Story writing experience}

Firstly, the teacher candidates made their stories written. Their experiences in this process are seen in the following expressions:

“...I think I can write a story. I have already attempted to write a story even in an unprofessional way, and my knowledge was also refreshed. There will be characters in story certainly, but I think I will make these characters fantastic because I think it will be more interesting..." (T1).

“...I took the notes that will facilitate my job in the story creation stage by finding the example substances for all features that characterize the substance. I searched as a subject on the characteristics specified in the achievements. The story writing phase should consist of 3 main chapters: Introduction, development and result. I must always use the same time frame during the story. My draft plan is ready..." (T3). 
"... What can I do before beginning the story? How can I be fun? How can I pay attention? Can the story be understood according to the mass that I want to teach? I thought things like that its heading must be avocatory. I planned to write my story in the form of a test for purpose of allowing the substances to talk things in the form of fables or allowing the children to notice things that they always encounter in their daily life, but are unobtrusive..." (T4).

“...But, because it is an easy and fun subject, it will be fun to tell, research and narrate for me. I also think of writing a dialogue through characters, taking the interests and skills of Grade 4 children into account and writing them to draw attention to the subject. In order to write a good story, I must give importance to subject integrity, event pattern, time, space and character concepts. Since the granular and hollow structure was not included in the 4th grade level, it was necessary to explain it by simplifying it more without talking about this concept. I had difficulty to state any particular achievements based on some restrictions. I was indecisive whether I can find appropriate materials in the digital story section to describe the spaces and concepts I have designed in my draft story materially and discretely by adding people and emotions ..."(T5).

"...I didn't have difficulty a little bit to create characters or draw attention while I describe the characters or achievements of the story, but I think that I will have a little bit to correlate the event and characters each other. First thing that I pay attention is to draw attention and not to bore. The content images are for type sizes. Actually, it was the challenge for me. Other things to do are easier than that, so it is easier to tell by dividing the story. Other thing to be done is describe the subject, that is, the story by dividing it. It is more interesting to describe the frozen, melting and state change with a character basis by making the ice, water and vapor a character. It was difficult to adapt it to the 4th grade students. I tried to choose a simple expression and a simple presentation. I would write it by making it a character, but when I tried, I could not it. I wrote and finished it as a simple story..." (T6).

From the statements, it is seen that the teacher candidates are aware that the story must have a title, that they should take a place to the characters, and that events should be arranged as introduction development and result, when the given story creation training and previous knowledge of the teacher candidates are also considered. Furthermore they stated that the story and the characters in it should be attention grabbing, and how the story will draw attention, and how to make it fun. However, it is seen from their expressions that they must write their stories in line with specific issues and achievements. 


\section{Digital story creation experience}

After the teacher candidates write their stories, they digitized these stories by using the GoAnimate software. In this process, they made the steps of vocalizing and recording the written stories through the microphone, creating the images, adding the sound and images to the software, combining the added images to sound, giving the movie any effects if the software is appropriate and converting the work into video format. Experiences in this process are given in the following statements:

"...I had to change the subject and event pattern, because I could not find the things that I wanted in digitizing the events and subjects. However, the new story was good, but the digital version of my story was highly incomplete due to the software..."(T1).

"...I experienced many positive and negative things, but I had a lot of fun while I do it at the beginning. I studied the Goanimate software in more detail and made a nice study. If you examine the negative aspects of the software, I had a great difficulty to understand, because it was not in Turkish. Also it is so complicated and I cannot do exactly what I want. I was a good study. I appreciate the course teacher..."(T2)

"I am very happy because I learn to use and prepare a digital story. But I spent a lot of time in creating it. I tried to find a lot of people to vocalize. I couldn't find any children to vocalize the child character in my study. It was difficult for me. I realized that I did by researching a lot of information. It helped me to understand this subject completely"(T4).

“...Obviously I don't like to use a computer too much. But I think that it is useful for me to learn how to use these software programs, because I know that our era is technology era and that many students will use computers better than me in the future. When I vocalized and prepared the stages in the Goanimate software, I tried very hard. I tried to describe the information that I wanted to give with shorter sentences, because sometimes the recording duration of the scenes is long and sometimes the duration of the dialogs is long. It was necessary to extend the stages, because only one character could talk in the Goanimate software in each scene. Since I did not have a personal computer and I was prepared upon a long effort, I experienced any time-related problems in correcting the stages and adding the voice. I made an effort a little bit more, because I could not find suitable images in the Goanimate software and I had to adhere to the script..."(T5).

"...It was clear in my head. Lastly, departing from negotiations between the municipal employees I studied the pure substances and mixtures, but I think I will have difficulty to provide these images in the software. When I transferred it to the computer program, I thought to change some dialogs of the story that I have prepared and instead to complete it with another sentence in accordance with the achievements..." (T7) 
The teacher candidates stated that they had difficulty to use the GoAnimate software, that they couldn't find the things that they wanted in the software, that they could not understand because it was not in Turkish, they spent a lot of time, that they had difficulty to vocalize for different characters, that recorded the stages together with the voice, and therefore that they changed the stages. The teacher candidates stated they learnt something, they had developed themselves and had a lot of fun in this process, while they researched anything, even if they had difficulty to use the software.

\section{Opinions of the Teacher Candidates on the Use of Stories and Digital Stories in Science Teaching}

After the teacher candidates wrote the stories and transferred these stories to digital media and created their digital stories, they stated their opinions on the use of stories and digital stories in science teaching, taking their experience into consideration The questions asked in the structured interview forms prepared by the researchers were accepted as the main theme and the opinions of the teacher candidates were collected under 5 main themes as seen in Figure 3.

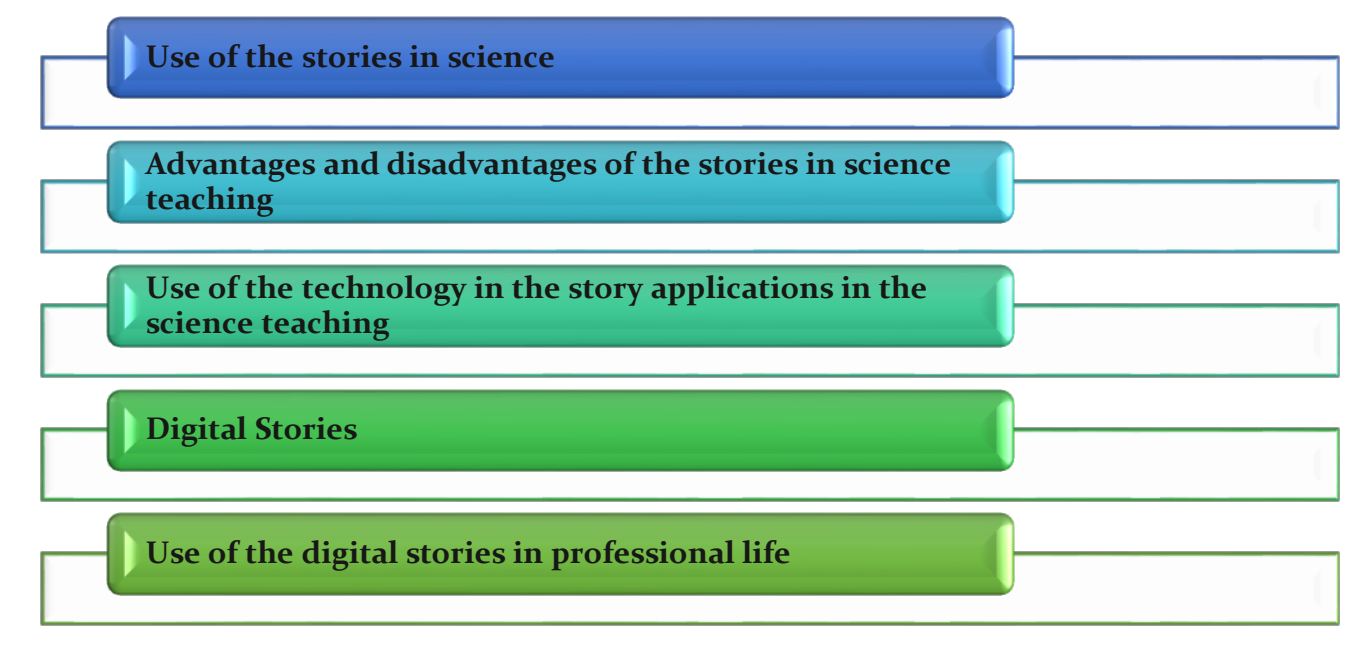

Figure 3. The themes including the opinions of the teacher candidates on use of the stories and digital studies in science teaching.

The examples of the prospective teachers were given under each theme and it was endeavored to explain their opinions on the use of the stories and digital stories in science teaching. 


\section{Use of the stories in science}

When the statements about the use of the teacher candidates in science are analyzed, it is determined that the use of the stories make a positive contribution.

"...The use of the stories is a necessary method to deceive easily the described events used not only in our department, but also in all sections. The topics we want to describe in the stories are placed in a fiction and if we make that fiction interesting, the stories become more striking and our students will understand them easily and will not forget them easily, because they are in a certain fiction..."(T1). "...Story is a good helper to feature the creativity. Thanks to the stories, the students are more productive in the classroom ..." (T2).

“...Placing a story in the science courses draws attention of students as well as attracts interest, curiosity and desire, because I think that it is more fun to the course. It creates an environment in which they can both have fun and learn..."(Ö5).

“...The stories make it easy to attract children's attention. The course contributes to the longer and more efficient understanding process, while the course is taught ..."(T6).

".... Since the science course is a course based on visualization, if we communicate some topics and concepts verbally, this never leads to permanent expressions in the mind of the student. But, I believe, with this story method, it will lead to any associations in mind through the relevant images while it transfers the necessary subject, and thus I believe that I will have obtained a fun course content at the same time, while we have fun..."(T7).

The teacher candidates have said that the use of the science in science could be used not only in the field of sciences, but also in all learning fields. They pointed out that, upon the use of stories, the courses would be more interesting and more fun and thus would inspire curiosity and desire.

It is seen in the expression of the teacher candidates that the students will focus on the courses for a longer time and create a more efficient learning environment. 


\section{Advantages and disadvantages of using the stories in science teaching}

The teacher candidates' expressions are given under two main themes: Advantages and disadvantages.

\section{Advantages}

The teacher candidates have expressed a lot of positive opinions about the use of the stories in science:

"...It allows us to describe anything to the children in an easier and understandable way. It provides a more memorability than a normal expression. It increases the interest of the children to the subject. The Children's imagination evolves..." (T1).

“...It provides effective, fun, thought-provoking, curious learning. It gives ability to remember the learnt subject easier and imagine it concretely and improves the desire of learning and the interest of students in the course ..."(T5).

"...It may improve the ability to conceive at a young age and make the learning easier..."(T6).

“...It may provide more permanent information skills by a fun story technique rather than the information which impose to memorize any boring verbal information..."(T7).

The teacher candidates stated that, if the science subjects were explained to the students in an easier and understandable way, this was important and made a great contribution to permanent learning. They also stated that it was efficient in making any discrete subjects concrete in majority of science, fun, intriguing, and would increase the interest of the students to the course.

\section{Disadvantages}

The teacher candidates also expressed any negative as well as many positive opinions about the use of the stories in science.

"...If the explained subject is heavy and incomprehensible, the children will have difficulty in understanding and the interest to the subject will be reduced. If any violent or negative examples are found in the stories, students may do the wrong things, thinking that this is the right thing to do..." (T1) 
"...In the stories, the children sing excessively into the imaginary, and when too many unreal characters are used (fairy, magic, talks of inanimate beings, etc.), they isolate themselves from the real world. Disadvantages include their the desire that the courses are taught just like a story..."(T5).

"...It can make it difficult to gain reading habits. It may be described by a shape story up to the high school subjects, but afterwards we will not have such a chance and there may be any problem for a transition period ... "(T6).

"...I think that it must be treated sensitively when using the story technique. An incorrect image or incomplete information leads the student to imagine the incorrect information in his mind..."(T7).

In the expressions of the teacher candidates, it is stated that, while the story technique is used, selection of the topics and the fictionalized events and characters can cause the students to get overwhelmed in the world of imagination and can have a negative effect on their abstraction from the real world. The teacher candidates stated that the disadvantages of the use of the stories included the facts that they could cause a greater ambiguity in the subjects situations that were heavy and difficult to understand, and there were any attitudes to constitute violence and negative examples unintentionally.

\section{Use of the technology in the story applications in the science teaching}

The teacher candidates emphasize the importance of using the technology in the science courses. The teachers, who follow any developments in information technology, will league together with the students, who follow and use the technology closely, in more permanent learning environments by using them in computer animations, simulations, visual and audio materials.

"...We need to adapt to the use of different applications on the computer for story use. This is an example of the fact that both teachers and students use technology in the most positive way positively. Its result will be good, even if correlation of the technology to the course forces the teacher a little bit..." (T3)

"...According my idea on use of the technology, it is essential that there are things to draw attention of the children. The subject should never be deviated while using it, and all students should be taken into account when using ..."(T4)

"...We can prepare them as any cartoons or videos by using the websites such as Goanimate, Prezi, Toondo, Powtoon, etc. while the stories were transferred to the technological media. Or we can share videos with our students by creating a school blog (which can be created from the blogging tab in our gmail site tools)...."(T5) 
"...The information that is desired to be given may be narrated by many animation software programs, and in these software programs, the information may be correlated and applied to the necessary characters. It will be an advantage for us to be fully informed about the use of programs to obtain healthier data..."(T7)

The teacher candidates believe that technology should be used without deviating from the subject that animations can be applied in the courses by using the simulation and animation programs, and that technological communication with students can also be provided by blogs. Even if we think that adapting the technology to the courses will force teachers a little bit, both teachers and students point out that technology is important to use positively in the most useful way.

\section{Digital Storytelling}

When the expressions of the teachers on the digital storytelling are examined, it can be said that digital storytelling forms effective and remarkable learning environments in terms of today's technology era and technology children.

"...The digital storytelling is better than normal story, because normal story tries to hear and understand the students only, but in the digital storytelling, visualization will also enter into story and make the students easier, and their interest the required subject and event will be higher..." (T1)

“...Through the digital storytelling, the students understand and learn better. The digital storytelling is also very helpful to draw attention of the students to the course and enable them to participate in it. The images always draw attention. But, students should not get used to it, because they don't have to be lazy to write. Everything cannot be learned by watching or listening..." (T2)

"...Because our era is the technology era, and most of the children are very interested in any tools such as tablet PCs, computers, telephones, etc. in using the technology, they contribute positively to the presentation of digital media as a story in their courses and also create an impression in the student's mind. The parents, who complain that their children play a lot of computer games, may find positive feedback to their teachers when their children listen to lessons instead of playing games on the computer. This makes the teacher happy because it makes the course effective..." (T5).

"...If the images are also in normal story, the digital story cannot hold its place in digital storytelling. There are a lot of advantages in using it for dubbing, and today's children's curiosity to technology is to many and they never leave their tablet PCs from their hands...."(T6). 
The teacher candidates stated that the students would not draw attention of the students too much, because only texts and pictures exist in the stories, but digital stories would be more interesting by using the dubbing and animations as well as the digital story, that it would contribute to the motivation and permanent learning of the courses by the studies. They state that today's technology is important for children to use this kind of technology with both educational and entertaining activities consciously. They think that, if the students make use of technology intentionally instead of playing games constantly, this will make both teachers and parents happy.

\section{Use of the digital stories in professional life}

Teacher candidates stated that they would use the digital storytelling method, when they were teachers.

"...I find myself sufficient. I already learned the digital stories. Now I have more knowledge on these matters. I find myself sufficient on qualification. I don't understand a perfect digital story, but I do it. I can prepare the content, subject and images very easy. I think to use it frequently when I am a teacher..."(T2)

"...Firstly, my first job will to do the digital storytelling as we did in the course. And while the course is taught, the relevant video demonstrations, the presentations that I have prepared by the students and computers will be under my hand during the experiment demos..."(T3)

"...I can find myself sufficient now. I can use these software programs to give any achievements based on more abstract concepts that are difficult for students to understand, when I am teachers. But I also think that I can do stages and dubbings better in programs. While I watch the videos of our friends, I think I have developed a more different point of view about the course subjects, while we watch the videos of our colleagues in the classroom..."(T5)

"...It is definitely a technique that I would like to use in my future teaching experience. Now I do not think that I have the ability to use the applications exactly. If I develop a little, I think I can make the story appropriate to the achievements..."(T7)

The teacher candidates stated that they would use the digital storytelling in their professional life, but they would take steps to improve themselves, even if they found $\mathrm{h}$ to prepare a digital story as a result of these applications. They also expressed that they developed different 
perspectives on the subject of science and that they would frequently use it in their professional lives.

\section{Discussion and Conclusion}

In this research, we aimed to determine the opinions of science candidates about the use of the stories and digital stories in science teaching by considering their experiences after writing the story about the achievements of the 3rd and 4th class science lessons and creating these the digital stories. The findings obtained from the data were evaluated under two main headings: The experiences of teacher candidates about the digital story creation and the opinions about the use of digital stories in science teaching. The experiences of the teacher candidates' experiences are divided into two sub-themes: Story writing experience and digital story creation experience. The opinions of prospective teachers on the use of stories and digital stories in science teaching are collected under 5 main themes: "The use of the science stories," "the advantages and disadvantages of using the science stories," "the use of technology in scientific science," "digital storytelling," and "the use of digital story in professional life." While teacher candidates created their stories, they created existing story writing experiences and post-training stories they received. In this process, they designed their stories by taking the introduction, development and result steps toward the achievements into account, and they defined the characters. They take care that they are interesting and fun, when they determine the events and characters. They stated that they had difficulty to relate the events in the story to the achievements. In the study that Sancar-Tokmak, Sürmeli and Özgelen (2012) conducted with the science teacher candidates, it is stated that the section that the teacher candidates have mostly difficulty is a story writing stage, and at this stage, they expressed that they prepared stories that contain misconceptions, that they changed the stories because they don't these stories interesting, that they could not descend to the student' level when they write the appropriate story for achievements, and that the story writing stage requires creativity. In this context, it is important that the written story is adapted well to the course subject and provide the necessary background for digital storytelling (Turgut \& Kışla, 2015).

After the teacher candidates wrote their stories, they digitized them by using the GoAnimate software. It is observed that the teacher candidates have difficulty to use the GoAnimate 
software. In their study, Kapucu, Eren and Avc1 (2014) concluded that the teacher candidates had difficulty to prepare the educational animations by using the GoAnimate software and that it would be difficult to adapt the prepared educational animations to each topic. They argued that they could not find what they wanted in the software, they couldn't understand it, because the software language was English and that the preparation process was time-consuming. Furthermore, they had difficulty to make dubbing for different characters and when they were combined with the sound, the stages deviated, and they had to change their stories many times. Robin and McNeil (2012) emphasize the key components of the digital story process. These components include selecting a meaningful topic, developing a well-structured text, working with high-quality media files, and incorporating an on-going evaluation process into the students. Although the teacher candidates stated that they had difficulty in using the program, they said that these difficulties and the events they had experienced developed themselves in using the program. They expressed that they learned while researching and that they had a lot of fun and developed their creativity during the process. The opinions that the digital story process is fun events that support active learning in the classroom environment are supported by various studies (Hung, Hwang, \& Huang, 2012; Kocaman-Karoğlu, 2014; Wang \& Zhan, 2010).

It is concluded that the stories are used under the theme of "the use of the stories in science" which consists of the opinions of the teacher candidates about the use of stories and digital stories in science teaching, is useful in terms of making the courses more interesting and fun and giving students curiosity and attention and focusing on the lesson. Similar results can also be observed in the study, where the pinions of the teachers on the benefits of doing digital storytelling practices with pre-school students are examined. Especially, it is observed that the digital story applications are interesting experiences that contribute to the development of technological and visualization skills, which are remarkable, fun, support active participation, contribute to achievement of concrete experiences, enable to work on the product, support the emergence of different skills (Kocaman- Karoğlu, 2016). Emphasis has also been placed on the fact that the use of stories should not be limited to science classes.

Under the theme of "Advantages and disadvantages of using stories in science", which is formed by the opinions of the teacher candidates about the use of short stories and digital stories in science teaching, the teacher candidates think that, in addition to the advantages of using 
stories, they may have disadvantages if they are not used carelessly and correctly. As a positive opinion, they stated that it is a great contribution to the learning permanently what is important in terms of telling science subjects to students more easily and comprehensibly.

They are an effective, amusing, intriguing, and augmenting of the interest of the students in the concretization of abstract subjects in a large part of the sciences. Students will be able to easily configure their knowledge by linking science lessons with everyday events through digital stories. Thus, the students will not get bored and will be able to learn more easily by associating their knowledge with their previous learning (Kahraman, 2013). Van Gils (2005) also emphasized that the use of the digital stories in education is a curiosity and an effective way for active learning, adding to teaching diversity, enabling education to be personalized, interesting and relevant to real-life situations. As a negative opinion, they pointed out that the students could get away from the real world by getting too much in the world of fantasy, and the carelessly prepared stories could lead to meaning and concept confusion unintentionally. They pointed out the disadvantages of using the stories include violence or negative behaviors in expression of the events.

Under the theme of "Using technology in science teaching", which is based on the opinions of the teacher candidates about the use of short stories and digital stories in science teaching, the teacher candidates think that the use of technology in science teaching can be achieved by using blogs with technological communication with the students, where applications can be done in class by using different animation analogies and animation programs. In this regard, they stressed that although teachers may have difficulty in time and preparation for implementation.

The teacher candidates under the theme of "digital storytelling ", which is formed by the opinions of the teacher candidates about the use of stories and digital stories in science teaching, are more interesting because they are created from voices and animations together with pictures, unlike normal stories. They stated that students will be effective in motivational and permanent learning.

In his study, Erişti (2016) concludes that the digital storytelling approach is an effective environment for qualified learners who can avoid using their limited time to learn effectively and efficiently based on lack of motivation. According to traditional methods, the use of 
animation in the teaching of abstract and complex subjects has been found to be more effective in increasing student achievement (Aksoy, 2013; Pekdağ, 2010; Rohendi, 2012). Also, instead of spending inefficient time with technological tools, students will be happy with their beneficial activities to make use of technology with their correct and conscious use of their learning.

The teacher candidates stated that they would use the digital stories in their professional life under the theme of "using the digital story in professional life", which is made up of teacher candidates' views on the use of short stories and digital storytelling in science teaching. In this sense, they have expressed that they are aware of the need for both students and students to include applications to prepare digital stories and to develop them in spite of the fact that they see themselves adequately. In this way they have said that the creativity of both students and teachers will improve.

Senemoğlu (2007) emphasized that, in order to develop creativity, the teacher must first be equipped with these qualities before him, and that his creative qualities must carry him first. Growth of creative generations is possible with the teachers who can think fluently, flexibly and originally, and organize the necessary environments for it. In this context, it is important for the teacher candidates participating in the research to be aware of their imagination and creativity and to give opinions in positive terms. By means of digital storytelling, different viewpoints have taught that they have developed their happiness in getting out of a uniform science teaching and will often use it in their professional lives. Effective participation in digital storytelling process; creative thinking skills, imagination, research skills and technological competencies are developing; motivations and academic achievements are also increasing (Duman \& Göcen, 2015; Duveskog, Tedre, Sedano, \& Sutinen, 2012; Hung, Hwang, \& Huang, 2012; Jakes \& Brennan, 2005; Karataş, Bozkurt, \& Hava, 2016; Kocaman-Karoğlu, 2016; Ohler, 2006; Özpınar, 2017; Robin, 2008; Yang \& Wu, 2012).

When all these main and subscale results are evaluated, it can be said that teacher candidates should be included in digital sciences in science courses, that digital stories pay attention to the subject, they are fun and curious, and that permanent learning is possible. In the studies done in the related literature, it is seen that the students of digital storytelling have positively influenced and improved the course success (Barrett, 2006; Demirer, 2013; Doğan, 2007; 
Hung, Hwang, \& Huang, 2012; Yang \& Wu, 2012; Yüksel, Robin, \& McNeil, 2011). There are also studies that show a better and more in-depth understanding of the learning experience that facilitates learning (Barrett, 2006; Bromberg, Techatassanasoontorn, \& Andrade 2013; Dupain \& Maguire, 2005;). The teacher candidates have stated that digital fictions in science teaching will be effective in their professional lives, and that these practices make them aware of their own deficiencies in the use of technology in science lessons and as teacher candidates. As a result of the findings and conclusions obtained from this research, studies on the use of digital stories in science should be increased and training and lessons should be given to prospective teachers so that they can improve themselves. They must acquire skills to prepare and prepare scientific stories supplemented by technology. 


\section{References}

Aksoy, G. (2013). Effect of computer animation technique on students' comprehension of the "solar system and beyond" unit in the science and technology course. Mevlana International Journal of Education (MIJE), 3(1), 40-46.

Balaman, F. (2016). Dijital öyküleme'nin üniversite öğrencilerinin demokratik değer yargılarına etkisi: Mustafa Kemal Üniversitesi örneği. Current Research in Education, 2(1), 42-52.

Barrett, H. (2006). Researching and evaluating digital storytelling as a deep learning tool. Technology and Teacher Education Annual, 1, 647.

Boase, K. 2008. Digital storytelling for reflection and engagement: A study of the uses and potential of digital storytelling. Retrieved February 12, 2009 from http://resources.glos.ac.uk/tli/lets/projects/pathfinder/index.cfm.

Bromberg, N. R., Techatassanasoontorn, A. A., \& Andrade, A. D. (2013). Engaging students: Digital storytelling in information systems learning. Pasific Asia Journal of the Association for Information Systems, 5(1), 1-22.

Cole, G. K., Street, K. E., \& Felt, L. J. (2013). Storytelling in the digital age: Engaging learners for cognitive and affective gains. International Journal of Technology, Knowledge and Society, 8(6), 113-119.

Demirer, V. (2013). İlkögrretimde e-öyküleme kullanımı ve etkileri (Yayınlanmamış Doktora Tezi). Necmettin Erbakan Üniversitesi. Konya.

Dogan, B. (2007). Implementation of digital storytelling in the classroom by teachers trained in a digital storytelling workshop. (Unpublished doctoral dissertation). University of Houston. Retrieved from ProQuest Digital Dissertations. (UMI 3272583)

Duman, B., \& Göcen, G. (2015). The effect of the digital storytelling method on pre-service teachers' creative writing skills. Anthropologist, 20(1-2), 215-222. 
Dupain, M., \& Maguire, L. (2005). Digital storybook projects 101: How to create and implement digital storytelling into your curriculum. In $21^{\text {st }}$ Annual Conference on Distance Teaching and Learning (Vol. 6, p. 2014).

Duveskog, M., Tedre, M., Sedano, C. I. \& Sutinen, E. (2012). Life planning by digital storytelling in a primary school in Rural Tanzania. Educational Technology \& Society, 15(4), 225-237.

Erişti, S. D. B.(2016). Katılımcı tasarım temelli dijital öyküleme sürecinde ilköğretim öğrencilerinin yaratıcılık göstergeleri. Turkish Online Journal of Qualitative Inquiry (TOJQI). 7(4), 462-492.

Gömleksiz, M. N. (2004). Use of education technology in English classes. The Turkish Online Journal of Educational Technology - TOJET, 3(2), 71-77.

Hung, C. M., Hwang, G. J., \& Huang, I. (2012). A project-based digital storytelling approach for improving students' learning motivation, problem-solving competence and learning achievement. Educational Technology \& Society, 15(4), 368-379.

Jakes, D. S., \& Brennan, J. (2005). Capturing stories, capturing lives: An introduction to digital storytelling. Retrieved from www.jakesonline.org/dstory_ice.pdf (01.03.2017).

Jakes, D. (2006). Standards-proof your digital storytelling efforts. TechLearning, Retrieved fromhttp://mcgeef.pbworks.com/f/StandardsProof+Your+Digital+Storytelling+Efforts. pdf

Kahraman, Ö. (2013). Dijital hikayecilik metoduyla hazırlanan öğretim materyallerinin öğrenme döngüsü giriş aşamasında kullanılmasının fizik dersi başarısı ve motivasyonu düzeyine etkisi. (Doktora tezi). Balıkesir Üniversitesi, Fen Bilimleri Enstitüsü, Balıkesir.

Kapucu, M. S., Eren, E., \& Avc1, Z. Y. (2014). Fen Bilgisi öğretmen adaylarının animasyon oluşturmada goanimate kullanımına ilişkin görüşlerinin incelenmesi. Turkish Online Journal of Qualitative Inquiry, 5(4), 23-40.

Karataş, S., Bozkurt, Ş. B., \& Hava, K. (2016). The perspective of history pre-service teachers' towards the use of digital storytelling in educational environments. Journal of Human Sciences, 13(1), 500-509. 
Kocaman-Karoğlu, A. (2014). Personal voices in higher education: A digital storytelling experience for pre-service teachers. Education and Information Technologies, 1-16. DOI 10.1007/s10639-014-9373-1

Kocaman-Karoğlu, A. (2016). Okul öncesi eğitimde teknoloji entegrasyonu: dijital hikâye anlatımı üzerine öğretmen görüşleri. Turkish Online Journal of Qualitative Inquiry (TOJQI), 7(1), 175-205.

Kotluk, N., \& Kocakaya, S. (2015). 21. yüzyıl becerilerinin gelişiminde dijital öykülemeler: Ortaöğretim öğrencilerinin görüşlerinin incelenmesi. Eğitim ve Öğretim Araştırmaları Dergisi, 4(2), 354-363.

Ohler, J. (2006). The world of digital storytelling. Educational Leadership, 63(4), 44-47.

Özpınar, İ. (2017). Matematik öğretmeni adaylarının dijital öyküleme süreci ve dijital öykülerin öğretim ortamlarında kullanımına yönelik görüşleri. Bartın Üniversitesi Egitim Fakültesi Dergisi, 6(3), 1189-1210.

Pekdağ, B. (2010). Alternative methods in learning Chemistry: Learning with Animation, Simulation, Video and Multimedia. Journal of Turkish Science Education, 7(2), 111-118.

Raven, J., \& O'Donnell, K. (2010). Using digital storytelling to build a sense of national identity amongst Emirati students. Education, Business and Society: Contemporary Middle Eastern Issues, 3(3), 201-217.

Robin, B. R. (2008). Digital storytelling: A powerful technology tool for the 21 st century classroom. Theory Into Practice, 47, 220-228.

Robin, B. R., \& McNeil, S. G. (2012). What educators should know about teaching digital storytelling. Digital Education Review, 22, 37-51.

Rohendi, D. (2012). Developing e-learning based on animation content for improving mathematical connection abilities in high school students. International Journal of Computer Science Issues (IJCSI), 9(4), 1-5.

Sancar-Tokmak, H., Sürmeli, H., \& Özgelen, S. (2014). Preservice science teachers' perceptions of their tpack development after creating digital stories. International Journal of Environmental and Science Education, 9(3), 247-264. 
Schnotz, W. (2001). Educational promises of multimedia learning from a cognitive perspective, Multimedia Learning: Cognitive and Instructional Issues. Amsterdam: Elsevier, p: 9-29.

Senemoğlu, N. (2007). Gelişim öğrenme ve ögretim [Development, learning and teaching]. Ankara: Gönül Yayıncılık.

Suwardy, T., Pan, G., \& Seow, P. S. (2013). Using digital storytelling to engage student learning. Accounting Education, 22(2), 109-124.

Turgut, G., \& Kışla, T. (2015). Bilgisayar destekli hikâye anlatımı yöntemi: Alanyazın araştırmas1. Turkish Online Journal of Qualitative Inquiry, 6(2), 97-121.

Wang, S., \& Zhan, H. (2010). Enhancing teaching and learning with digital storytelling. International Journal of Information and Communication Technology Education (IJICTE), 6(2), 76-87.

Van Gils, F. (2005, June). Potential applications of digital storytelling in education. In 3rd Twente Student Conference on IT (Vol. 7). University of Twente, Faculty of Electrical Engineering, Mathematics and Computer Science Enschede.

Yang, Y.T.C., \& Wu, W.C.I. (2012). Digital storytelling for enhancing student academic achievement, critical thinking, and learning motivation. A year - long experimental study. Computers \& Education, 59(2), 339- 352.

Yıldırım, A., \& Şimşek, H. (2003). Sosyal bilimlerde nitel araştırma yöntemleri. Ankara: Seçkin Yayınları.

Yuksel, P., Robin, B., \& McNeil, S. (2011). Educational uses of digital storytelling all around the world. In Society for Information Technology \& Teacher Education International Conference (Vol. 2011, No. 1, pp. 1264-1271). 